Cambodian Economy 
The Institute of Southeast Asian Studies (ISEAS) was established as an autonomous organization in 1968. It is a regional centre dedicated to the study of socio-political, security and economic trends and developments in Southeast Asia and its wider geostrategic and economic environment. The Institute's research programmes are the Regional Economic Studies (RES, including ASEAN and APEC), Regional Strategic and Political Studies (RSPS), and Regional Social and Cultural Studies (RSCS).

ISEAS Publishing, an established academic press, has issued more than 2,000 books and journals. It is the largest scholarly publisher of research about Southeast Asia from within the region. ISEAS Publishing works with many other academic and trade publishers and distributors to disseminate important research and analyses from and about Southeast Asia to the rest of the world. 


\section{Cambodian Economy}

Charting the Course of a Brighter Future A Survey of Progress, Problems and Prospects

Hang Chuon Naron

\section{누반ㄷ}


First published in Singapore in 2012 by

ISEAS Publishing

Institute of Southeast Asian Studies

30 Heng Mui Keng Terrace, Pasir Panjang

Singapore 119614

E-mail: publish@iseas.edu.sg

Website: http://bookshop.iseas.edu.sg

for worldwide distribution.

Reprinted and published by permission of the author.

First published in Phnom Penh in 2009. The publication of the original edition was funded by the Asian Development Bank.

\section{(C) 2009 Hang Chuon Naron}

All rights reserved. No part of this publication may be reproduced, stored in a retrieval system, or transmitted in any form or by any means, electronic, mechanical, photocopying, recording, or otherwise, without written permission of the publisher.

The responsibility for facts and opinions in this publication rests exclusively with the author and his interpretations do not necessarily reflect the views or the policies of ISEAS or its supporters.

\section{ISEAS Library Cataloguing-in-Publication Data}

Hang, Chuon Naron.

Cambodian economy : charting the course of a brighter future : a survey of progress, problems and prospects.

1. Cambodia-Economic conditions.

2. Cambodia-Economic policy.

I. Title.

HC442 H23 2012

2012

ISBN 978-981-4311-60-1 (soft cover)

Cover photo: Cambodia's Great King - Jayavarman VII.

Source: Hang Chuon Naron.

Printed in Cambodia by Sunway Publishing 